\title{
GMR
}

\section{Molecular cloning and differential expression of the glucocorticoid receptorgene in the estuarine tapertail anchovy Coilia nasus}

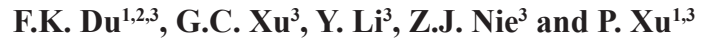 \\ ${ }^{1}$ Wuxi Fisheries College, Nanjing Agriculture University, Wuxi, China \\ ${ }^{2}$ Jiangsu Red Grease Crab Co. Ltd., Xinghua, Jiangsu, China \\ ${ }^{3}$ Key Laboratory of Freshwater Fisheries and Germplasm Resources Utilization, \\ Ministry of Agriculture, Freshwater Fisheries Research Center, \\ Chinese Academy of Fishery Sciences, Wuxi, China \\ Corresponding author: P. Xu \\ E-mail: xup13806190669@163.com
}

Genet. Mol. Res. 16 (2): gmr16029125

Received September 1, 2016

Accepted March 21, 2017

Published May 10, 2017

DOI http://dx.doi.org/10.4238/gmr16029125

Copyright $(C 2017$ The Authors. This is an open-access article distributed under the terms of the Creative Commons Attribution ShareAlike (CC BY-SA) 4.0 License.

\begin{abstract}
To understand the regulation of the glucocorticoid receptor gene ( $G c r)$ during loading and transport stress in fish, the $G c r$ gene of Coilia nasus was cloned. Gcr in C. nasus is expressed strongly in the liver and muscle, and less stronglyin the gills, brain, spleen, intestine, trunk kidney, and head kidney. Gcr expression in both the liver and muscle was increased by loading and transport stress. $\mathrm{NaCl}$ reduced the death rate caused by loading and transport stress, and the expression of $\mathrm{Gcr}$ in liver and muscle differed significantly between the $\mathrm{NaCl}$ and non- $\mathrm{NaCl}$ groups. To investigate whether the elevated $\mathrm{Gcr}$ transcripts were translated into protein, proteins extracted from the liver and muscle were analyzed. In both tissues, C. nasus GCR protein expression patterns paralleled those of Gcr mRNA during stress.
\end{abstract}

Key words: Coilia nasus; Glucocorticoid receptor; Stress; $\mathrm{NaCl}$; Hypothalamus-pituitary-interrenal; Rapid amplification of cDNA ends

Genetics and Molecular Research 16 (2): gmr16029125 


\section{INTRODUCTION}

The hypothalamus-pituitary-interrenal (HPI) axis, or the stress axis, regulates the stress responses and is highly conserved across vertebrates (Wendelaar Bonga, 1997; Barton et al., 2002). The activation of the HPI axis begins in the hypothalamus (Wunderink et al., 2011), which secretes cortisol releasing factor (CRF) and stimulates the release of adrenocorticotrophic hormone $(\mathrm{ACTH})$ from the pituitary. This pituitary peptide binds to the melanocortin 2 receptor (MC2R) on steroidogenic cells in the interrenal tissue, leading to corticosteroidogenesis (Aluru and Vijayan, 2008, 2009). Cortisol represents the end product of the HPI axis and influences the expression of responsive genes (Gower, 1993; Dekloet et al., 1998), which in turn influence many functions of the central nervous system in mammals, including arousal, cognition, mood, sleep, metabolism, cardiovascular tone, and the immune and inflammatory reactions (Kino, 2007; Chrousos and Kino, 2009; Srinivasan et al., 2013). In teleost fish, cortisol can be significantly increased by stress, therefore, this hormone is always regarded as a stress marker. Cortisol can enhance the mobilization of liver glycogen, resulting in increased production of endogenous glucose (Lopez-Patino et al., 2014). The biological function of cortisol is mediated by its receptors, and the glucocorticoid receptor (GCR) is one of the most important. As a result, the glucocorticoid receptor gene $(\mathrm{Gcr})$ is a vital gene in responding to stress.

The estuarine tapertail anchovy Coilia nasus (Temminck and Schlegel, 1846) is widely distributed in Korea, Japan, and the Yangtze Riverandcoastal waters of China (Jiang et al., 2012). Its nutritive value and taste make it a commercially important species. However, C. nasus is highly susceptible to stress, which often results in death, causing significant losses to the industry. Although Gcr is an important gene in the stress response, little is known about the regulation of the Gcr gene during loading and transport stress in this fish. We found that the number of deaths caused by stress in $C$. nasus can be reduced by $\mathrm{NaCl}$, therefore, in this study, we have examined in detail how the cortisol, Gcr and plasma osmolality levels respond to stress and $\mathrm{NaCl}$ treatment.

\section{MATERIAL AND METHODS}

\section{Animal welfare}

Animal welfare and experimental procedures were carried out in accordance with the guide for the Care and Use of Laboratory Animals (Ministry of Science and Technology of China, 2006), and were approved by the animal ethics committee of the Chinese Academy of Fishery Sciences (2014JBFR06).

\section{Experimental animals}

C. nasus were adapted to a $7.0 \times 5.0 \times 1.0 \mathrm{~m}^{3}$ aquarium with a water temperature

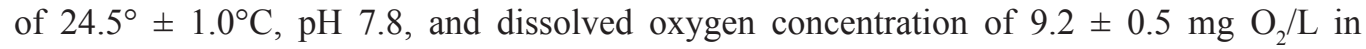
dechlorinated, aerated water. The fish were fed twice daily, at 07:00 hours and 17:00 hours. At the outset of the experiments, all the fish appeared healthy.

\section{Cloning and sequencing of $C$. nasus $G c r$}

TRIzol Reagent (Invitrogen, Carlsbad, CA, USA) was used to extract total RNA from

Genetics and Molecular Research 16 (2): gmr16029125 
the liver. APrimeScript RT Reagent Kit with gDNA Eraser (Takara, Osaka, Japan) was used to synthesize the first-strand cDNA. ClustalX 1.83 multiple-alignment software was used to align the Gcr nucleotide sequences from a variety of species. Primers were designed based on the nucleotides conserved in the sequences of 11 species reported previously: Homo sapiens, Pan troglodytes, Macaca mulatta, Canis lupus familiaris, Gallus gallus, Mus musculus, Rattus norvegicus, Danio rerio, Takifugu rubripes, Oryzias latipes and Oncorhynchus mykiss (Table 1). A 562-bp fragment of the Gcr gene was amplified from the $C$. nasus liver cDNA using the primer pair 10S/14A (Table 2). The 5' and 3' ends of the C. nasus $G c r$ cDNA were obtained by rapid amplification of cDNA ends (RACE) (Zhuan Dao, Wuhan, China).

Table 1. GenBank accession numbers of GCR sequences used in this study.

\begin{tabular}{l|l}
\hline Species & Accession No. \\
\hline Homo sapiens & NP_001019265.1 \\
\hline Pan troglodytes & XP_001155243.1 \\
\hline Macaca mulatta & XP_001097126.1 \\
\hline Bos Taurus & NP_001193563.1 \\
\hline Canis familiaris & XP_535225.2 \\
\hline Gallus gallus & NP_001032915.1 \\
\hline Mus musculus & NP_032199.3 \\
\hline Rattus norvegicus & NP_036708.2 \\
\hline Oncorhynchus mykiss & NP_001117954.1 \\
\hline Oryzias latipes & NP_001156605.1 \\
\hline Danio rerio & NP_001018547.2 \\
\hline
\end{tabular}

Table 2. Sequences of primers used in this study.

\begin{tabular}{l|l|l}
\hline Primer & Sequence & Usage \\
\hline R844-1 & GGACGAAGCACAGCAT & $5^{\prime}$ RACE \\
\hline R844-3 & GCAGCAGGGTCATCTGGTCG & 5'RACE \\
\hline $502-1$ & TGGCAGAGGTTCTACCAGCTCACCA & 3'RACE \\
\hline $502-2$ & CATGACATGGTGGGCGGCCTGCTGA & 3'RACE \\
\hline $10 \mathrm{~S}$ & AAATGGGCTAAAGCTCTGCCAG & Homologous cloning forward primer \\
\hline $14 \mathrm{~A}$ & TTGGTAACTGGTTGCTGATGATTTC & Homologous cloning reverse primer \\
\hline $25 \mathrm{~S}$ & TGCTCCTGGCTCTTCCTCATG & Forward primer for CnGCR RT-qPCR \\
\hline $25 \mathrm{~A}$ & TGCAGACGCACAAACTCGTTG & Reverse primer for Cn $G C R$ RT-qPCR \\
\hline $42 \mathrm{~S}$ & TGATTGGGACTGGGGATTGAA & Forward primer for 18 sRNA RT-qPCR \\
\hline $42 \mathrm{~A}$ & TAGCGACGGGCGGTGTGT & Reverse primer for 18 sRNA RT-qPCR \\
\hline B1 & AACGGATCCGGTATGTGCAAAGC & Forward primer for $a c t b 1$ RT-qPCR \\
\hline B2 & GGGTCAGGATACCTCTCTTGCTCTG & Reverse primer for $a c t b 1$ RT-qPCR \\
\hline
\end{tabular}

\section{Reverse transcription-quantitative PCR (RT-qPCR) analysis of CnGcr mRNA expression profiles}

Total RNA was extracted and first-strand cDNA was synthesized as described above. RT-qPCR was used to determine the C. nasus Gcr expression profiles, using $18 s R N A$ as the reference gene for detection of expression levels in different tissues, and actb1 (encoding $\beta$-actin) was used for stress response detection. $25 \mathrm{~S} / 25 \mathrm{~A}$ was used to amplify $G c r, 18$ sRNA (42S/42A) and $a c t b 1$ (B1/B2) (Table 2) had similar melting temperatures (Tm) and were designed to amplify 136- and 179-bp fragments, respectively. SYBR ${ }^{\circledR}$ Green Real time PCR Master Mix (Takara) was used to perform the RT-qPCR, with the following cycling parameters: $94^{\circ} \mathrm{C}$ for $2 \mathrm{~min}$, followed by 40 cycles of $15 \mathrm{~s}$ at $94^{\circ} \mathrm{C}, 34 \mathrm{~s}$ at $60^{\circ} \mathrm{C}$, and $45 \mathrm{~s}$ at $72^{\circ} \mathrm{C}$. All the samples were analyzed in triplicate and the expression of the target genes was calculated (fold

Genetics and Molecular Research 16 (2): gmr16029125 
change) with the $2^{-\Delta \Delta C t}$ method. The expression levels of each gene were normalized to the reference gene, and then the data were expressed as the ratio of the CnGCR mRNA expression in the tissue to its expression in muscle.

\section{Stress experiment}

The C. nasus juveniles used in the experiment had been cultured in three $7.0 \times 5.0 \mathrm{x}$ $1.0 \mathrm{~m}^{3}$ ponds for one year. When the fish were 15 months old, five fish were removed from each pond and euthanized with $70 \mathrm{mg} / \mathrm{L}$ buffered tricaine methanesulfonate (MS-222). These 15 fish were the non-stressed controls. Another 75 fish were netted from each pond and 15 were loaded into each of 15 tanks (volume: $75 \times 55 \times 33 \mathrm{~cm}^{3}$ ). These 15 tanks were divided into five groups of three tanks each, from which fish were sampled at different time points. The tanks were shaken once every 5 min over the course of $0,2,4,6$, or $8 \mathrm{~h}$ to simulate transport, and five fish from each tank were euthanized. The mean length of all the fish $(\mathrm{N}=90)$ sampled in this experiment was $136.98 \mathrm{~mm} \pm 9.26$ (S.M.) and their mean mass was $8.86 \mathrm{~g} \pm 1.76 \mathrm{~g}$.

Another 75 fish were netted from the same ponds and subjected to the same experimental procedure, except that $1.0 \% \mathrm{NaCl}$ was included in the water. The mean length of all the fish $(\mathrm{N}=$ 90) sampled in this experiment was $141.46 \mathrm{~mm} \pm 11.99$ and their mean mass was $9.93 \mathrm{~g} \pm 5.06$.

Blood was collected into CAD (citric acid) capillary tubes after the caudal fin was severed. All fish appeared healthy during dissection, and the tissues were removed and placed in TRIzol Reagent. The plasma was separated by centrifugation, and the plasma and tissue samples were stored at $-80^{\circ} \mathrm{C}$ until analysis. Total RNA extraction, cDNA synthesis, and RTqPCR were performed as described above.

All mRNA levels are reported as means $\pm \mathrm{SD}$ and were subjected to two-way analysis of variance (ANOVA). Differences were considered significant at $\mathrm{P} \leq 0.05$.

\section{Cortisol, glucose, and plasma osmolality}

Plasma cortisol was quantified using the radioimmunoassay described by Redding et al. (1984). Plasma glucose was quantified using the protocol described by Admin and Tasd (1977), and it was measured at $635 \mathrm{~nm}$ on a Beckman Cx-4 spectrophotometer (Beckman Coulter, Fullerton, CA, USA). Plasma osmolality was quantified using anOsmomat030 osmometer (Gonotec, Berlin, Germany).

Two-way ANOVA was used to analyze the differences among the times-post-transport in the same group, and the differences between the with- $\mathrm{NaCl}$ and without-NaCl treatment groups. The survival rates were tested by Chi-square tests $(\mathrm{P}<0.05)$.

\section{Western blotting}

Western blotting was conducted according to Du et al. (2016). The KeyGEN Whole Cell Lysis Assay (KeyGEN, Nanjing, China) was used to extract tissue protein and the bicinchonininc acid (BCA) method (Pierce, Bonn, Germany) was used to determine protein content. The anti-GCR antibody (Bioss, Beijing, China) and the anti-actin antibody (Aviva, London, England) were diluted 1:5000 with $10 \mathrm{mM}$ PBS (pH 7.4). The horseradish-peroxidaselabeled goat anti-rabbit IgG antibody (Aviva, London, England) was diluted 1:5000. The bands were visualized with Pierce ECL Plus (Thermo Fisher Scientific, Waltham, MA, USA).

Genetics and Molecular Research 16 (2): gmr16029125 


\section{RESULTS}

\section{Cloning and sequence characterization of the $C$. nasus $G c r$ gene}

A 562-bp cDNA fragment was amplified from C. nasus liver cDNA. A BLASTx analysis of the sequence showed that it shared strong similarity with other $G c r$ genes. Based on this conserved sequence, the full-length cDNA of $C$. nasus Gcr (GenBank accession No.: KJ747634) was obtained with RACE. Its full length was 3175 bp and it contained a 2379-bp open reading frame (ORF) encoding a protein of 792 amino acids. The 5' and 3 ' untranslated regions were 89 and $707 \mathrm{bp}$, respectively. One polyadenylation signal (AATAAA) was present 13 nucleotides upstream from the polyA tail. The identities shared by the deduced $C$. nasus Gcr amino acid sequence and its homolog used in other species were: D. rerio $52 \%$, G. gallus $42 \%$, . norvegicus $41 \%$, M. musculus $41 \%$, B. taurus $41 \%$, C. lupus familiaris $41 \%$, M. mulatta $41 \%$, P. troglodytes $40 \%$ and $H$. sapiens $40 \%$ (Figure $1 \mathrm{~A}$ ). The C. nasus GCR protein was predicted to contain a GCR domain (350 residues), a $\mathrm{ZnF}-\mathrm{C} 4$ domain (81 residues), and a HOLI domain (165 residues) (Figure 1B).

A

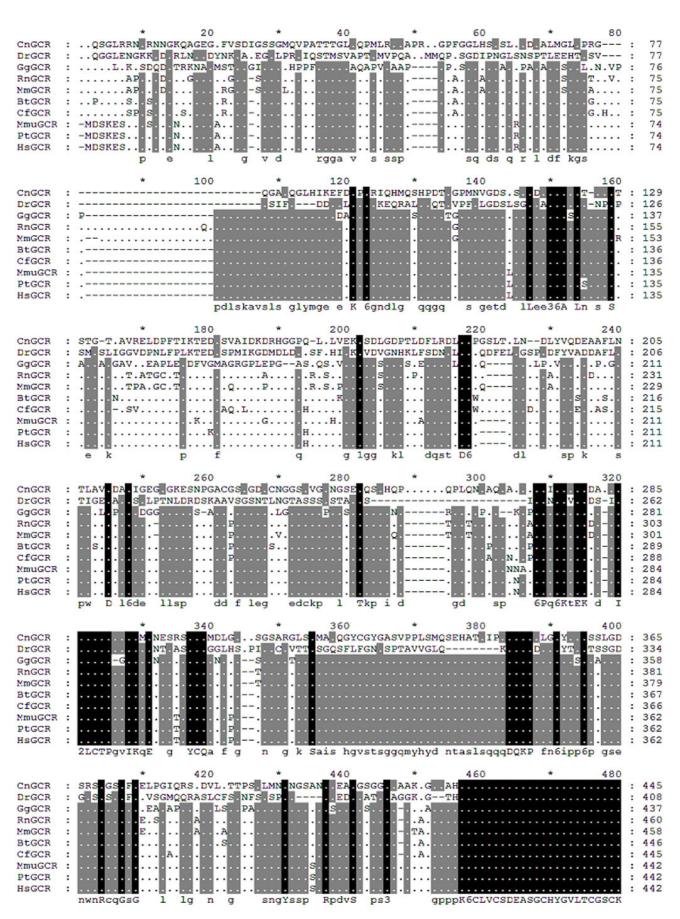

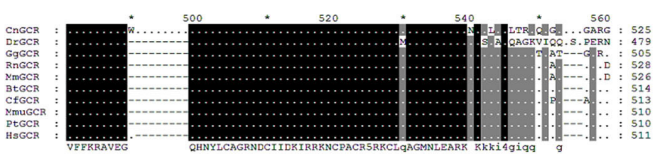
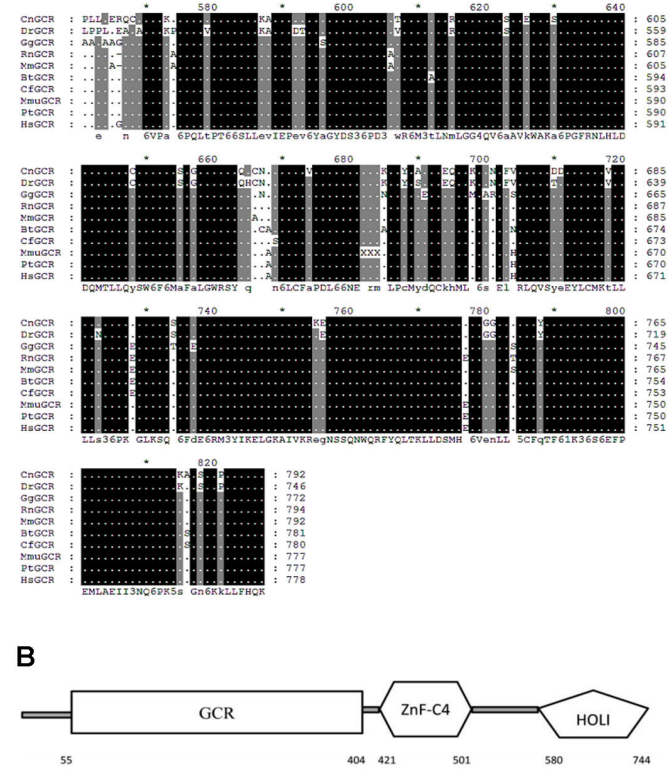

Figure 1. Deduced amino acid sequence and predicted domain structure of CnGCR. A. Alignment of the deduced amino acid sequence of $\mathrm{CnGCR}$ and other reported GCR sequences. The residues completely conserved across all species are aligned and shaded in black. Cn, Coilia nasus; Dr, Danio rerio; Gg, Gallus gallus; Rn, Rattus norvegicus; Mm, Mus musculus; Bt, Bos taurus; Cf, Canis lupus familiaris; Mmu, Macaca mulatta; Pt, Pan troglodytes; Hs, Homo sapiens. B. Schematic diagram of the structure of CnGCR, which comprises a GCR domain, a $\mathrm{ZnF}-\mathrm{C} 4$ domain, and a HOLI domain. 


\section{Tissue expression profiles of $\mathrm{CnGcr}$}

The expression profiles of the C. nasus Gcr transcripts were assessed in different tissues with RT-qPCR, using $18 s R N A$ as the reference gene. In healthy fish, C. nasus Gcr was strongly expressed in liver and muscle, and less strongly in the gill, brain, spleen, intestine, kidney, and head kidney (Figure 2).

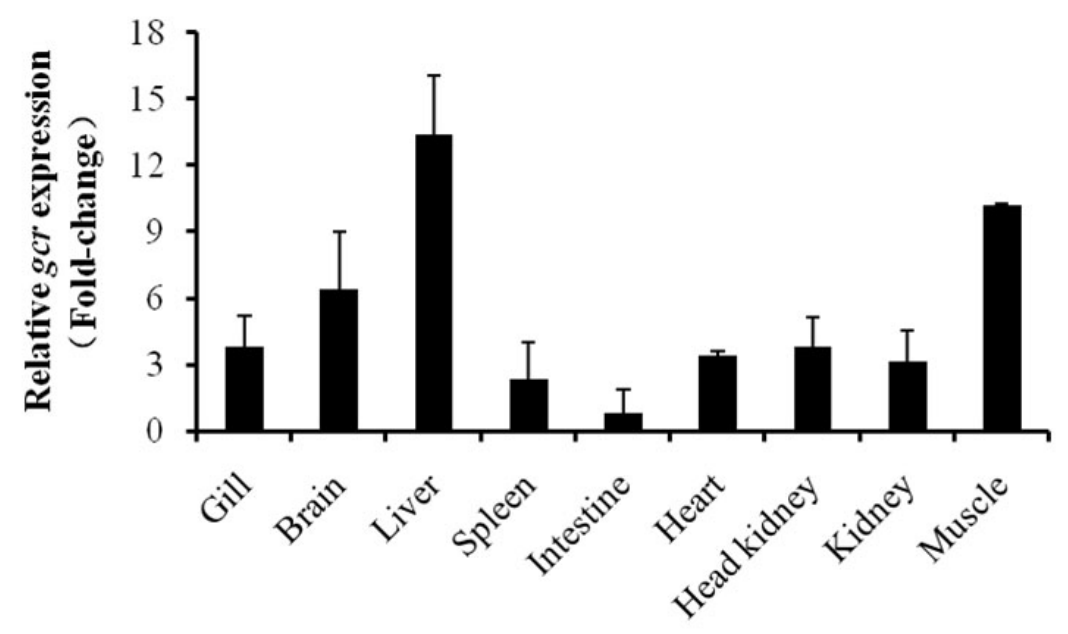

Figure 2. CnGCR mRNA expression in different tissues. RT-qPCR analysis of the expression profiles of CnGCR mRNA in different $C$. nasus tissues. Data are expressed as the ratio of CnGCR mRNA expression in the tissue to its expression in muscle (means $\pm \mathrm{SD}$ ).

\section{Survival rate and plasma osmolality}

After simulated transport, the survival rate decreased to $73.0 \%$ in the non- $\mathrm{NaCl}$ group (Figure $3 \mathrm{~A}$ ). $\mathrm{NaCl}(1.0 \%)$ was then added to the transport tanks to reduce the death rate caused by stress, and there were no dead fish in the $1.0 \% \mathrm{NaCl}$ group (Figure 3A). When the plasma osmolality was determined in both groups (Figure 3B), it differed significantly between the non- $\mathrm{NaCl}$ and $\mathrm{NaCl}$ groups $(\mathrm{P}<0.05)$. Plasma osmolality was significantly elevated after loading $(0 \mathrm{~h})$, but then decreased significantly in the non- $\mathrm{NaCl}$ group. Unlike the non- $\mathrm{NaCl}$ group, plasma osmolality increased significantly in the $\mathrm{NaCl}$ group compared with the control fish, but was maintained at a level similar to the control level after loading.

\section{Plasma cortisol and glucose responses to stress}

In the non- $\mathrm{NaCl}$ group, plasma cortisol was significantly elevated in the stressed fish $(\mathrm{P}<0.05)$ compared to the control fish $(187.76 \mathrm{ng} / \mathrm{mL} \pm 9.07 ; \mathrm{N}=15)$ (Figure 4A). There were no significant differences between the control replicates $(\mathrm{P}>0.05)$. In the $\mathrm{NaCl}$ group, plasma cortisol in the stressed fish was also significantly elevated $(\mathrm{P}<0.05)$ compared to the control fish (Figure 4A), and it was significantly higher in the $\mathrm{NaCl}$ group than in the non- $\mathrm{NaCl}$ group at $4 \mathrm{~h}(\mathrm{P}<0.05)$. 

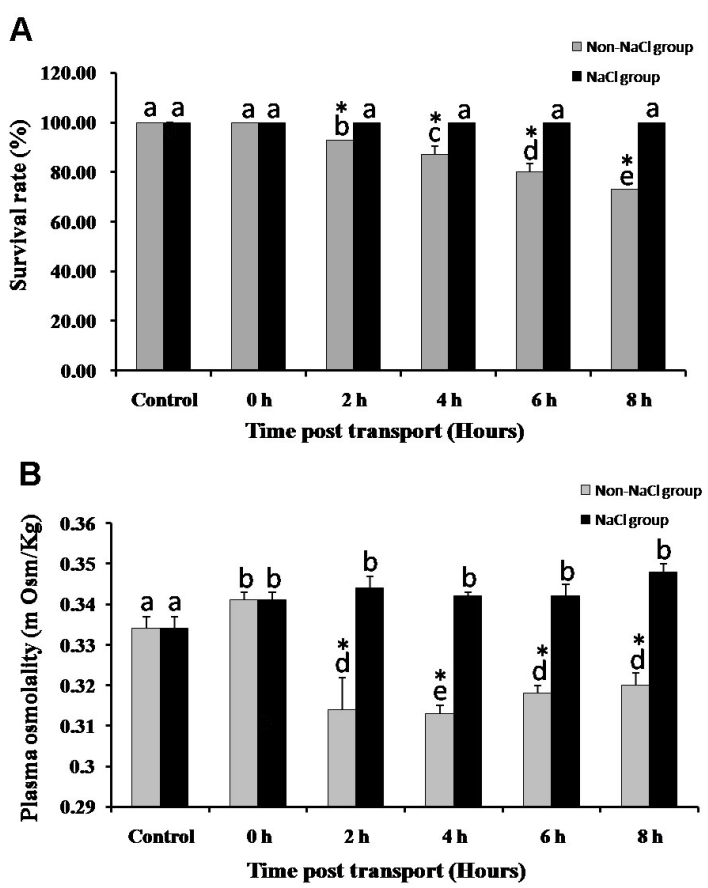

Figure 3. Survival rate and plasma osmolality of fish during loading and transport stress. Bars are the means $\pm \mathrm{SD}$ of replicate experiments. a,b,c,d,e Different letters represent significant differences between the control and different times after stress $(\mathrm{P}<0.05)$. *Significant difference $(\mathrm{P}<0.05)$ between the non-NaCl group and $\mathrm{NaCl}$ group at the same time point. A. Survival rate during loading and transport stress in the non- $\mathrm{NaCl}$ group and $\mathrm{NaCl}$ group. $\mathbf{B}$. Plasma osmolality levels during loading and transport stress.

In the non- $\mathrm{NaCl}$ group, plasma glucose concentration (Figure 4B) was significantly elevated $(\mathrm{P}<0.05)$ after the fish were netted $(6.31 \pm 0.20 \mathrm{mM} ; \mathrm{N}=15)$ and transported for $2 \mathrm{~h}$ $(8.38 \pm 0.81 \mathrm{mM} ; \mathrm{N}=15)$, and it decreased after $6 \mathrm{~h}(4.96 \pm 0.44 \mathrm{mM} ; \mathrm{N}=15)$ and $8 \mathrm{~h}(4.81$ $\pm 0.78 \mathrm{mM} ; \mathrm{N}=15)$ of transport, although it was still significantly higher than in the control $(4.03 \pm 0.66 \mathrm{mM} ; \mathrm{P}<0.05, \mathrm{~N}=15)$. After transport for $4 \mathrm{~h}$, the plasma glucose concentration $(4.53 \pm 0.49 \mathrm{mM} ; \mathrm{N}=15)$ was not significantly different from the control. In the $\mathrm{NaCl}$ group (Figure 4B), a similar pattern of change was observed, but the plasma glucose concentrations after treatment for 2,6 , and $8 \mathrm{~h}$ were significantly higher in the non- $\mathrm{NaCl}$ group than in the $\mathrm{NaCl}$ group $(\mathrm{P}<0.05, \mathrm{~N}=15)$.

\section{CnGcrresponses to stress}

In the non- $\mathrm{NaCl}$ group, RT-qPCR revealed a 3.3-6.3-fold increase in the expression of $G c r$ in the livers of the stressed C. nasus (P $<0.05$; Figure 5A). Similarly, a 6.5-10.2-fold increase in the expression of C. nasus Gcr was observed in muscle (Figure 5B). In the $\mathrm{NaCl}$ group, RT-qPCR revealed a 6.3-11.0-fold increase in the expression of $G c r$ in the livers of the stressed C. nasus ( $\mathrm{P}<0.05$; Figure 5A). Similarly, a 6.0-8.4-fold increase in the expression of C. nasus Gcr was observed in muscle (Figure 5B). Therefore, the expression of C. nasus Gcr in both liver and muscle differed significantly between the non- $\mathrm{NaCl}$ and $\mathrm{NaCl}$ groups. 
A

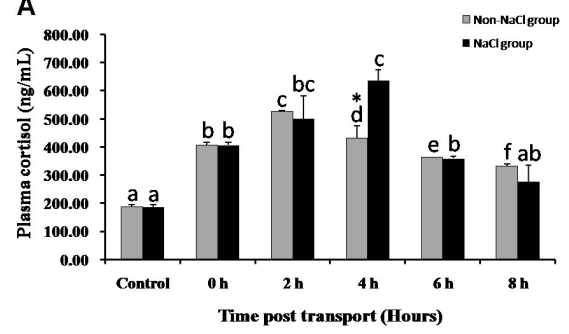

B

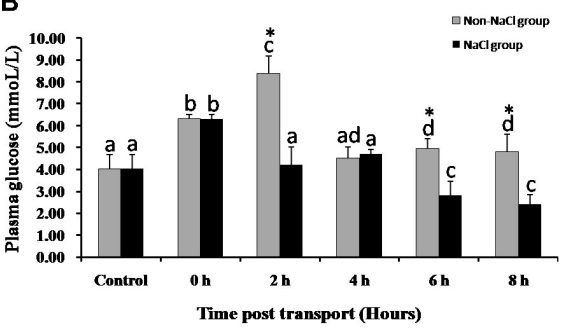

Figure 4. Plasma cortisol and plasma glucose concentrations during loading and transport stress. Bars are the means $\pm \mathrm{SD}$ of replicate experiments. a,b,c,d,e,fDifferent letters represent significant differences between the control and different times after stress $(\mathrm{P}<0.05)$. *Significant difference $(\mathrm{P}<0.05)$ between the non- $\mathrm{NaCl}$ group and $\mathrm{NaCl}$ group at the same time point. A. Plasma cortisol concentrations during loading and transport stress in the non- $\mathrm{NaCl}$ group and $\mathrm{NaCl}$ group. B. Plasma glucose levels during loading and transport stress in the non- $\mathrm{NaCl}$ group and $\mathrm{NaCl}$ group.
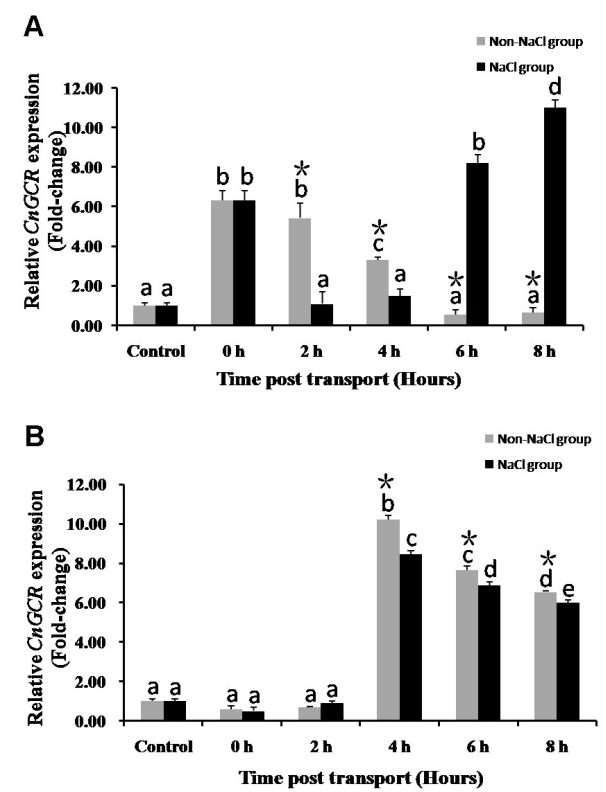

Figure 5. CnGCR mRNA responses to stress. Bars are the means \pm SD of replicate experiments. ${ }^{\text {a,b,c,d Different }}$ letters represent significant differences between the control and different times after stress $(\mathrm{P}<0.05)$. Significant difference $(\mathrm{P}<0.05)$ between the non- $\mathrm{NaCl}$ group and $\mathrm{NaCl}$ group at the same time point. A. Expression profiles of liver CnGCR mRNA during stress in the non- $\mathrm{NaCl}$ group and $\mathrm{NaCl}$ group. B. Expression profiles of muscle CnGCR mRNA during stress in the non- $\mathrm{NaCl}$ group and $\mathrm{NaCl}$ group.

Genetics and Molecular Research 16 (2): gmr16029125 
To investigate whether the elevated $\mathrm{Gcr}$ transcripts were translated into protein, proteins extracted from liver and muscle were analyzed with western blotting. The antibodyspecific detection of these two protein extracts are shown in Figure 6A and B. In both tissues, the C. nasus GCR protein expression patterns were similar to the mRNA expression patterns during stress. In the non-NaCl group, liver GCR increased and peaked after 0 and $2 \mathrm{~h}$ of stress, after which it decreased (Figure 6C). However, in the $\mathrm{NaCl}$ group, GCR expression was significantly down-regulated after 2 and $4 \mathrm{~h}$ of stress and significantly up-regulated after 6 and $8 \mathrm{~h}$ of stress. GCR protein expression in the muscle also peaked $4 \mathrm{~h}$ after stress, and then decreased, although it remained high (Figure 6D). In the $\mathrm{NaCl}$ group, GCR protein expression was significantly down-regulated in muscle relative to the non- $\mathrm{NaCl}$ group (Figure 6D).

A

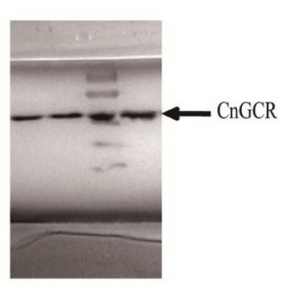

C
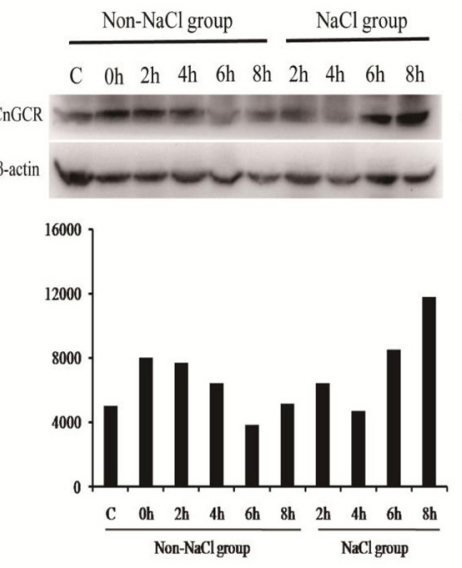

B

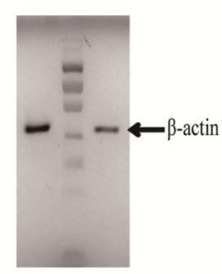

D
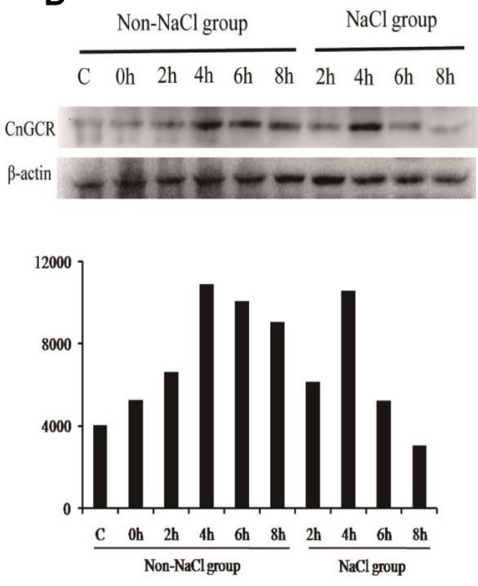

Figure 6. CnGCR protein responses to stress. A. Specific detection of CnGCR antibody. B. Specific detection of $\beta$-actin antibody. C. Expression profiles of liver CnGCR protein during stress in the non- $\mathrm{NaCl}$ group and $\mathrm{NaCl}$ group. D. Expression profiles of muscle $\mathrm{CnGCR}$ protein during stress in the non- $\mathrm{NaCl}$ group and $\mathrm{NaCl}$ group.

\section{DISCUSSION}

A comparison of the amino acid sequences of $C$. nasus GCR and other GCRs from a variety of species (Figure 1A), including D. rerio, G. gallus, $R$. norvegicus, M. musculus, B. taurus, C. familiaris, M. mulatta, P. troglodytes, and H. sapiens, revealed that C. nasus GCR has the three conserved domains found in all GCRs: a GCR domain at the N-terminus, a ZnF-C4 domain, and a HOLI domain at the C-terminus (Figure 1B). The sequence identities of these domains were high across species, especially for the $\mathrm{ZnF}-\mathrm{C} 4$ and HOLI domains, 
at more than $80 \%$ relative to the proteins of other fishes and mammals. All the sequence characteristics of GCR indicate that C. nasus GCR, together with the GCRs of other fish, have similar functions to those observed in mammals.

As noted above, GCRs are crucial to the regulation of cardiovascular, metabolic, immunologic, and homeostatic functions. GCRs have an established link to physical and mental stress (Lee et al., 2013), and they are involved in regulating metabolic rates, skeletal muscle protein metabolism, liver gluconeogenesis, and hyperglycemia (Brillon et al., 1995). So GCRs are expressed quite ubiquitously in fish, especially in liver (Vijayan et al., 2003), gills (Kuo et al., 2013), and muscle (Rotllant et al., 1997). C. nasus Gcr mRNA is highly expressed in liver and muscle (Figure 2), which is consistent with the critical functions of cortisol in these tissues (Dean et al., 2003; Fontainhas et al., 2003; Marshall, 2003; Tripathi and Verma, 2004). Cortisol is a key mediator of stress-induced hyperglycemia, and importantly, it supports the increased energy demand associated with stress (Mommsen et al., 1999; Sapolsky et al., 2000). Cortisol is also a vital osmoregulatory factor, and both gluconeogenic metabolism and osmoregulation are mediated by Gcr (Hanson and Reshef, 1997; Vijayan et al., 2003). The liver is an important gluconeogenic tissue and muscle is one of the tissues involved in osmotic balance, so C. nasus $\mathrm{Gcr}$ is highly expressed in both these tissues.

C. nasus is highly susceptible to stress, (Du et al., 2014a,b). In our experiment, the death rate caused by loading and transport stress was reduced by $1.0 \% \mathrm{NaCl}$ (Figure $3 \mathrm{~A}$ ). In aquaculture practice, netting- and transport-induced stresses are reduced by adding salt to freshwater, a procedure that affects glucose concentrations and osmoregulation. The HPI axis is also known as the stress axis (Fryer et al., 1984; Bernier et al., 1999), and it consists of a cascade of hormones that regulate cortisol secretion from the interrenal tissue (Abraham et al., 2009). This hormone mediates stress-induced hyperglycemia and osmoregulation (Henderson and Jones, 1967; Mayer and Maetz, 1967). In our study, plasma cortisol was significantly elevated after stress in the non- $\mathrm{NaCl}$ group (Figure 4A), as it is in other fish. Plasma glucose concentrations were also significantly increased in the non- $\mathrm{NaCl}$ group (Figure 4B), but plasma osmolality decreased after stress (Figure 3B). Therefore, loading and transport stress altered the plasma glucose concentrations and osmolality of the fish. Osmoregulatory adjustments are very important for fish, because without appropriate regulation, death may result (Takei et al., 2006; Kammerer et al., 2010; Gilmour et al., 2012). As a result, some of the fish in the non- $\mathrm{NaCl}$ group died. However, no fish died in the $\mathrm{NaCl}$ group (Figure 3A). As reported, adding salt to an almost isotonic level creates an iso-osmotic environment that helps fish to osmoregulate more easily and is less energy demanding and less stressful compared to a hypo-osmotic freshwater environment (Zhou et al., 2003). When the cortisol levels in the two groups were compared, $\mathrm{NaCl}$ had no significant regulatory effect on the plasma cortisol levels in most samples (Figure 4A), whereas it regulated plasma glucose concentrations and maintained plasma osmolality at a stable level (Figure 3B and Figure 4B).

In the early stage of the $C$. nasus stress response, $\mathrm{NaCl}$ reduced liver $\mathrm{GCR}$ expression (Figure 5A and Figure 6C), but it stimulated GCR expression in the later stage of the stress response. This result indicates that negative feedback regulation is involved in this process. High plasma glucose may induce $\mathrm{NaCl}$ to inhibit GCR expression, which then reduces the glucose levels. Similarly, low plasma glucose induces $\mathrm{NaCl}$ to stimulate GCR expression, thus increasing the glucose levels. In short, $\mathrm{NaCl}$ maintains plasma glucose at a stable level during the stress process. $\mathrm{NaCl}$ ameliorated $\mathrm{CnGCR}$ expression in muscle after $4 \mathrm{~h}$ of stress, and also maintained the osmotic pressure at a stable level.

Genetics and Molecular Research 16 (2): gmr16029125 
In conclusion, as in other reported studies, we found that cortisol was significantly increased by stress, and this altered the plasma glucose concentrations and osmolality of the fish. $\mathrm{NaCl}$ increased the survival rate of the fish by regulating plasma glucose concentrations and maintaining plasma osmolality at a stable level. There may be a negative feedback pathway involved in this process that warrants further study.

\section{Conflicts of interest}

The authors declare no conflict of interest.

\section{ACKNOWLEDGMENTS}

Research supported by the Natural Science Foundation of Jiangsu Province, China (grant \#BK20140121), the Special Fund of the Chinese Central Government for Basic Scientific Research Operations in Commonwealth Research Institutes (grant \#2015JBFR06), and the Three New Projects of the Agricultural Aquaculture Program of Jiangsu Province (grant \#D2015-14).

\section{REFERENCES}

Abraham G, Allersmeier M, Gottschalk J, Schusser GF, et al. (2009). Effects of dermal dexamethasone application on $\mathrm{ACTH}$ and both basal and ACTH-stimulated cortisol concentration in normal horses. J. Vet. Pharmacol. Ther. 32: 379-387. http://dx.doi.org/10.1111/j.1365-2885.2008.01054.x

Admin WG and Tasd YW (1977). Clinical methods for the assessment of the effects of environmental stress on fish health. Tech. Pap. U. S. Fish Wildl. Serv. 44: 89-89.

Aluru N and Vijayan MM (2008). Molecular characterization, tissue-specific expression, and regulation of melanocortin 2 receptor in rainbow trout. Endocrinology 149: 4577-4588. http://dx.doi.org/10.1210/en.2008-0435

Aluru N and Vijayan MM (2009). Stress transcriptomics in fish: a role for genomic cortisol signaling. Gen. Comp. Endocrinol. 164: 142-150. http://dx.doi.org/10.1016/j.ygcen.2009.03.020

Barton BA, Morgan JD, Vijayan MM and Adams SM (2002). Physiological and condition-related indicators of environmental stress in fish. 1st edn. American Fisheries Society, Bethesda, Maryland.

Bernier NJ, Lin X and Peter RE (1999). Differential expression of corticotropin-releasing factor (CRF) and urotensin I precursor genes, and evidence of CRF gene expression regulated by cortisol in goldfish brain. Gen. Comp. Endocrinol. 116: 461-477. http://dx.doi.org/10.1006/gcen.1999.7386

Brillon DJ, Zheng B, Campbell RG and Matthews DE (1995). Effect of cortisol on energy expenditure and amino acid metabolism in humans. Amer. J. Physiol. 268: 501-513.

Chrousos GP and Kino T (2009). Glucocorticoid signaling in the cell. Expanding clinical implications to complex human behavioral and somatic disorders. Ann. N. Y. Acad. Sci. 1179: 153-166. http://dx.doi.org/10.1111/j.1749-6632.2009.04988.x

Dean DB, Whitlow ZW and Borski RJ (2003). Glucocorticoid receptor upregulation during seawater adaptation in a euryhaline teleost, the tilapia (Oreochromis mossambicus). Gen. Comp. Endocrinol. 132: 112-118. http://dx.doi. org/10.1016/S0016-6480(03)00053-4

De Kloet ER, Vreugdenhil E, Oitzl MS and Joëls M (1998). Brain corticosteroid receptor balance in health and disease. Endocr. Rev. 19: 269-301.

Du F, Xu G, Nie Z, Xu P, et al. (2014a). Molecular characterization and differential expression of the myostatin gene in Coilia nasus. Gene 543: 153-160. http://dx.doi.org/10.1016/j.gene.2014.03.016

Du F, Xu G, Nie Z, Xu P, et al. (2014b). Transcriptome analysis gene expression in the liver of Coilia nasus during the stress response. BMC Genomics 15: 558. http://dx.doi.org/10.1186/1471-2164-15-558

Du FK, Xu GC, Li Y, Nie ZJ, et al. (2016). Glyoxalase 1 gene of Coilia nasus: molecular characterization and differential expression during transport stress. Fish. Sci. 82: 719-728. http://dx.doi.org/10.1007/s12562-016-1003-y

Fontainhas FA, Gomes EF and Reis MA (2003). Effect of cortisol on some osmoregulatory parameters of the teleost after transference from freshwater to seawater. Arq. Bras. Med. Vet. Zootec. 55: 562-567. http://dx.doi.org/10.1590/S0102-

Genetics and Molecular Research 16 (2): gmr16029125 
$\underline{09352003000500008}$

Fryer J, Lederis K and Rivier J (1984). Cortisol inhibits the ACTH-releasing activity of urotensin I, CRF and sauvagine observed with superfused goldfish pituitary cells. Peptides 5: 925-930. http://dx.doi.org/10.1016/01969781(84)90118-9

Gilmour KM, Perry SF, Esbaugh AJ, Genz J, et al. (2012). Compensatory regulation of acid-base balance during salinity transfer in rainbow trout (Oncorhynchus mykiss). J. Comp. Physiol. B 182: 259-274. http://dx.doi.org/10.1007/ $\underline{\mathrm{s} 00360-011-0617-8}$

Gower WR, Jr. (1993). Mechanism of glucocorticoid action. J. Fla. Med. Assoc. 80: 697-700.

Hanson RW and Reshef L (1997). Regulation of phosphoenolpyruvate carboxykinase (gtp) gene expression. Annu. Rev. Biochem. 66: 581-611.

Henderson IW and Jones IC (1967). Endocrine influences on the net extrarenal fluxes of sodium and potassium in the European eel (Anguilla anguilla L.). J. Endocrinol. 37: 319-325. http://dx.doi.org/10.1677/joe.0.0370319

Jiang T, Yang J, Liu H and Shen XQ (2012). Life history of Coilia nasus from the Yellow Sea inferred from otolith Sr:Ca ratios. Environ. Biol. Fishes 95: 503-508. http://dx.doi.org/10.1007/s10641-012-0066-6

Kammerer BD, Cech JJ, Jr. and Kültz D (2010). Rapid changes in plasma cortisol, osmolality, and respiration in response to salinity stress in tilapia (Oreochromis mossambicus). Comp. Biochem. Physiol. A Mol. Integr. Physiol. 157: 260265. http://dx.doi.org/10.1016/j.cbpa.2010.07.009

Kino T (2007). Tissue glucocorticoid sensitivity: beyond stochastic regulation on the diverse actions of glucocorticoids. Horm. Metab. Res. 39: 420-424. http://dx.doi.org/10.1055/s-2007-980193

Kuo T, Harris CA and Wang JC (2013). Metabolic functions of glucocorticoid receptor in skeletal muscle. Mol. Cell. Endocrinol. 380: 79-88. http://dx.doi.org/10.1016/j.mce.2013.03.003

Lee SR, Kim HK, Song IS, Youm J, et al. (2013). Glucocorticoids and their receptors: insights into specific roles in mitochondria. Prog. Biophys. Mol. Biol. 112: 44-54. http://dx.doi.org/10.1016/j.pbiomolbio.2013.04.001

Lopez-Patino MA, Hernandez-Perez J, Gesto M, Libran-Perez M, et al. (2014). Short-term time course of liver metabolic response to acute handling stress in rainbow trout, Oncorhynchus mykiss. Comp. Biochem. Physiol., Part A. Mol. Integr. Physiol. 168: 40-49. http://dx.doi.org/10.1016/j.cbpa.2013.10.027

Marshall WS (2003). Rapid regulation of $\mathrm{NaCl}$ secretion by estuarine teleost fish: coping strategies for short-duration freshwater exposures. Biochim. Biophys. Acta 1618: 95-105. http://dx.doi.org/10.1016/j.bbamem.2003.10.015

Mayer N and Maetz J (1967). Pituitary-interrenal axis and osmoregulation in the salt water eel. Study of the intact animal with notes on disturbances of the mineral balance produced by the effect of "shock." C.R. Seances Acad. Sci. Ser. D. 264: 1632-1635.

Mommsen T, Vijayan M and Moon T (1999). Cortisol in teleosts: dynamics, mechanisms of action, and metabolic regulation. Rev. Fish Biol. Fish. 9: 211-268. http://dx.doi.org/10.1023/A:1008924418720

Perry SF, Goss GG and Fenwick JC (1992). Interrelationships between gill chloride cell morphology and calcium uptake in freshwater teleosts. Fish Physiol. Biochem. 10: 327-337. http://dx.doi.org/10.1007/BF00004482

Redding JM, Patiño R and Schreck CB (1984). Clearance of corticosteroids in yearling coho salmon, Oncorhynchus kisutch, in fresh water and seawater and after stress. Gen. Comp. Endocrinol. 54: 433-443. http://dx.doi.org/10.1016/0016-6480(84)90159-X

Rotllant J, Pavlidis M, Kentouri M, Abad ME, et al. (1997). Non-specific immune responses in the red porgy Pagrus pagrus after crowding stress. Aquaculture 156: 279-290. http://dx.doi.org/10.1016/S0044-8486(97)00075-6

Sapolsky RM, Romero LM and Munck AU (2000). How do glucocorticoids influence stress responses? Integrating permissive, suppressive, stimulatory, and preparative actions. Endocr. Rev. 21: 55-89.

Srinivasan S, Shariff M and Bartlett SE (2013). The role of the glucocorticoids in developing resilience to stress and addiction. Front. Psychiatry 4: 68. http://dx.doi.org/10.3389/fpsyt.2013.00068

Takei Y, Kawakoshi A, Tsukada T, Yuge S, et al. (2006). Contribution of comparative fish studies to general endocrinology: structure and function of some osmoregulatory hormones. J. Exp. Zoolog. A Comp. Exp. Biol. 305: 787-798. http:// dx.doi.org/10.1002/jez.a.309

Tripathi G and Verma P (2004). Sex-specific metabolic changes in the annual reproductive cycle of a freshwater catfish. Comp. Biochem. Physiol. B Biochem. Mol. Biol. 137: 101-106. http://dx.doi.org/10.1016/j.cbpc.2003.10.005

Vijayan MM, Raptis S and Sathiyaa R (2003). Cortisol treatment affects glucocorticoid receptor and glucocorticoidresponsive genes in the liver of rainbow trout. Gen. Comp. Endocrinol. 132: 256-263.

Wendelaar Bonga SE (1997). The stress response in fish. Physiol. Rev. 77: 591-625.

Wunderink YS, Engels S, Halm S, Yúfera M, et al. (2011). Chronic and acute stress responses in Senegalese sole (Solea senegalensis): the involvement of cortisol, CRH and CRH-BP. Gen. Comp. Endocrinol. 171: 203-210. http://dx.doi. org/10.1016/j.ygcen.2011.01.010

Zhou B, Kelly SP, Ianowski JP and Wood CM (2003). Effects of cortisol and prolactin on Na+ and Cl- transport in cultured branchial epithelia from FW rainbow trout. Am. J. Physiol. Regul. Integr. Comp. Physiol. 285: R1305-R1316. http:// dx.doi.org/10.1152/ajpregu.00704.2002

Genetics and Molecular Research 16 (2): gmr16029125 